\title{
КОМПЛЕКСНА ФІЗИЧНА РЕАБІЛІТАЦІЯ ПАЦІЄНТІВ ІЗ ОСТЕОХОНДРОЗОМ ПОПЕРЕКОВОГО ВІДДІЛУ ХРЕБТА
}

\author{
А. О. Голяченко, Х. Т. Рогава \\ Тернопільський національний медичний університет \\ імені І. Я. Горбачевського МОЗ Украӥни
}

У статті висвітлено методи реабілітації пацієнтів із остеохондрозом поперекового відділу хребта. Значну увагу приділено результатам, досягнутим завдяки комплексу вправ та заняттям на дошці Євмінова.

\section{COMPLEX PHYSICAL REHABILITATION OF PATIENTS WITH OSTEOCHONDROSIS OF LUMBAR SPINE}

\author{
A. O. Holiachenko, Kh. T. Rohava \\ I. Horbachevsky Ternopil National Medical University
}

The article describes the methods of rehabilitation of patients with osteochondrosis of the lumbar spine. Considerable attention is paid to the results achieved through a set of exercises and occupation on the board of Yevminov

Вступ. Питання дегенеративно-деструктивних уражень хребта складають одну з найскладніших та далеко не вирішених проблем медицини, які за розповсюдженістю та стійкою втратою працездатності посідають перші місця у структурі неврологічної захворюваності населення (70-80 \%).

Кількість хворих на поперековий остеохондроз в останні роки нестримно збільшується. За даними Всесвітньої організації охорони здоров'я (ВООЗ), від остеохондрозу хребта страждають 40-80 \%, серед яких не тільки люди похилого віку, а й зовсім молоді [1]. Питома вага клінічних неврологічних проявів остеохондрозу хребта серед захворювань периферійної нервової системи становить 67-95 \%. Окрім цього, рентгенологічні та клінічні ознаки остеохондрозу на сьогодні нерідко діагностують у підлітків 12-15 років [2]. Хронічний біль у спині $є$ однією з найгостріших медико-соціальних проблем, що завдають величезних економічних збитків суспільству.

Остеохондроз хребта - це мультифакторне захворювання, що характеризується дистрофічним ураженням хребцевих рухових сегментів, переважно їх передніх відділів, і проявляється поліморфними неврологічними симптомами [4]. Симптоми можуть

(с) А. О. Голяченко, Х. Т. Рогава, 2020 бути різними, але найчастіше про остеохондроз свідчать:

- гострий біль у попереку, особливо після фізичних навантажень;

- підвищене потовиділення;

- запаморочення, головний біль;

- оніміння і порушення нормального функціонування рук та ніг;

- судоми кінцівок.

Виділяють 4 стадії поперекового остеохондрозу:

1. Незначний дискомфорт не викликає великої уваги, тим більше, що після короткочасного відпочинку він відступає.

2. Через руйнування фіброзного кільця зменшується міжхребцева щілина. Через це постійно передавлюються судини і нервові закінчення, які проходять через цю ділянку. Після нічного сну відчувається біль у хребті, порушується його гнучкість.

3. Третя стадія захворювання характерна ще більшим деформуванням фіброзного кільця, руйнування переходять на кісткову тканину і провокують появу міжхребцевих гриж.

4. На останній стадії спостерігають інтенсивний біль, який не блокується знеболювальними препаратами. Може настати параліч кінцівок і порушення 
роботи внутрішніх органів. На цьому етапі захворювання пацієнта може врятувати лише хірургічне втручання [6].

Основна частина. За останні роки немедикаментозні методи все ширше використовують при лікуванні дистрофічних захворювань хребта і їх рефлекторних проявів [3], проте до цих пір залишається дискусійним питання про те, які дії і їх поєднання раціональніше використовувати залежно від клінічних проявів остеохондрозу, не приділено належної уваги психотерапії, що визначає особливу значущість психологічних факторів в усуненні хронічного болю в спині [5].

Д. В. Попович зі співавт. визначили ефективність впливу засобів фізичної реабілітації, комплексного застосування удосконалених методик лікувального масажу, комплексу лікувальної гімнастики статикодинамічних вправ та вправ на дошці Євмінова на хворих із остеохондрозом поперекового відділу хребта [3]. Автори стверджують, що комплексне використання удосконалених елементів лікувального масажу, вправ на дошці Євмінова та комплексу лікувальної гімнастики, статико-динамічних вправ значно підвищило ефективність реабілітації як при початкових, так і при клінічно виражених неврологічних проявах вертебрального остеохондрозу [7].

Мета масажу: домогтися знеболювального впливу; усунути гіпертонус м'язів; поліпшити функціональний стан центральної нервової системи.

При остеохондрозі попереково-крижового відділу хребта з корінцевим синдромом спостерігають різкий біль в попереково-крижовій ділянці, який може поширюватися за ходом сідничного нерва (задня поверхня стегна, гомілка, стопа) або стегнового (передня поверхня стегна). Може також відзначатися слабкість стопи.

Мета роботи полягала у визначенні взаємозв'язків, що основані на результатах клінічних та функціональних даних для виявлення основних факторів, що впливають на характер і напрямок процесу фізичної реабілітації людей з остеохондрозом поперекового відділу хребта.

Об'єктом дослідження були пацієнти, у яких виявлено остеохондроз поперекового відділу хребта, предметом дослідження стали засоби та методи фізичної реабілітації, які застосовують у реабілітації людей з остеохондрозом поперекового відділу хребта.

Завдання роботи - детальний аналіз наукової літератури з цієї проблеми, дослідити та проаналізу- вати методи і методики реабілітації при лікуванні та корекції остеохондрозу поперекового відділу хребта.

У ході аналізу медичних карт використано дані людей з діагнозом остеохондроз поперекового відділу хребта в стадії неповної та повної ремісії. Методи дослідження - аналіз спеціальної науково-методичної літератури; аналіз медичних карт, результатів комп'ютерних томограм і рентгенограм; клінічні методи дослідження; медико-біологічні методи дослідження; методи математичної статистики.

У нашому дослідженні брали участь 20 людей віком 40-60 років із діагностованим остеохондрозом поперекового відділу хребта. Хворих поділено на 2 групи: контрольну та експериментальну. Під час дослідження використано різноманітні методи дослідження стану опорно-рухової системи - ортопедичне і неврологічне обстеження, що включало як суб'єктивні (скарги, анамнез), так і об'єктивні методи дослідження (огляд, пальпаторне обстеження, діагностика зон шкірної гіперестезії, тригерних зон та функціональних блокад хребцево-рухових сегментів).

Необхідно відзначити, що в досліджених групах людей з остеохондрозом поперекового відділу хребта виявлено пацієнтів із різним характером порушення постави, що, в свою чергу, є одним із факторів розвитку цієї патології, виникнення неоптимального розподілу навантаження в міжхребцевих дисках і рефлекторних деформацій.

В обох групах, залежно від віку, характеру, локалізації і стадії захворювання, інтенсивності больового синдрому, активності процесу, симптоматики, супутніх захворювань, хворі пройшли курс фізичної реабілітації. В експериментальній групі, разом із комплексом лікувальної гімнастики статико-динамічних вправ, як і в контрольній групі, додатково застосовували лікувальний масаж, вправи на дошці Євмінова.

Висновки. Комплексне використання удосконалених елементів лікувального масажу, вправ на дошці Євмінова та комплексу лікувальної гімнастики статико-динамічних вправ значно підвищило ефективність реабілітації як при початкових, так і при клінічно виражених неврологічних проявах вертебрального остеохондрозу.

Аналіз безпосередніх результатів лікування довів, що комплексна система більш ефективно приводить до зникнення або зменшення больового та міотонічного синдромів, поліпшення функціонального стану хребта, стану психоемоційної сфери, підвищення якості життя пацієнтів. 


\section{СПИСОК ЛІТЕРАТУРИ}

1. Краснояружський А. Г. Комплексна фізична реабілітація хворих при попереково-крижовому остеохондрозі хребта / А. Г. Краснояружський, Н. Г. Гасанов, К. В. Омеляненко // Фізична реабілітація та рекреаційнооздоровчі технології. - 2016. - № 2. - С. 41-42.

2. Василенко О. Б. Физическая реабилитация больных остеохондрозом пояснично-крестцового отдела позвоночника в стадии ремиссии / О. Б. Василенко, Н. В. Степанова // Физическое воспитание студентов творческих специальностей. - 2007. - № 3. - С. 29-34.

3. Реабілітація хворих на остеохондроз хребта / Д. В. Попович, В. Б. Коваль, І. М. Салайда [та ін.] //Здобутки клінічної і експериментальної медицини. - 2017. - № 4. - С. 74-77.
4. Лазарева Е. Б. Физическая реабилитация при хирургическом лечении вертеброгенных поясничнокрестцовых синдромов : монография / Е. Б. Лазарева. - К. : Экспресс, 2012. - 328 с.

5. Авраменко О. М. Механотерапія у відновному лікуванні хворих на остеохондроз попереково-крижового відділу хребта / О. М. Авраменко // Слобожанський науково-спортивний вісник : [наук.-теор. вісн.]. - Харків : ХДАФК, 2013. - № 5. - С. 16-18.

6. Oliveira C. B. Clinical practice guidelines for the management of non-specific low back pain in primary care: an updated overview / C. B. Oliveira // European Spine Journal. - 2018. - No. 27 (11). - P. 2791-2803.

7. Козак Д. В. Фізична реабілітація та основи здорового способу життя / Д. В. Козак, Н. О. Давибіда. - Тернопіль : Укрмедкнига, 2005. - 199 с. 